ROCZNIKI TEOLOGICZNE

Tom LXVII, zeszyt $12-2020$

DOI: https://dx.doi.org/10.18290/rt206712-2

RENATA JANICKA-SZYSZKO

\title{
JĘZYKOWA KREACJA ŚWIĘTEGO HUBERTA NA PRZYKŁADZIE MIESIĘCZNIKA ,ŁOWIEC POLSKI”
}

\author{
THE LINGUISTIC CREATION OF SAINT HUBERT \\ ON THE EXAMPLE OF THE MONTHLY MAGAZINE "LOWIEC POLSKI"
}

\begin{abstract}
A bstract. The purpose of the text is to analyse the creation of Saint Hubert in the articles published from 2015 to 2019 in "Lowiec Polski" [Polish Hunter] — a hunting branch magazine. The patron was mentioned over 50 times in genre-varied texts such as articles, reports, wishes and greetings and notes. The linguistic image of St. Hubert has been created by various lexical and stylistic means. Apart from nominal and verbal forms there appear idioms, parallels, metaphoric expressions, words and phrases typical for hierarchic relations and knightly culture as well as both religious and hunting terminology. The analysis indicates the positive image of the patron of hunters in the excerpted texts. Saint Hubert cares for them, shows his mercy and plays a key roles during hunting when he rewards hunters with good fortune. The patron has a decisive role in hunters' lives as he is the souvereign for them both during their lifetime and after their death and the hunters serve him faithfully.
\end{abstract}

Key words: linguistics; lexis; semantics; Saint Hubert; patron.

Według autorów encyklopedii Religia. Encyklopedia $P W N$ „początkowo patronem nazywano męczennika pochowanego na terenie zamieszkałym przez jakąś wspólnotę wiernych; wspólnoty bez grobu świętego starały się o relikwie, dopóki każda parafia i kościół nie znalazły się pod opieką jakiegoś świętego orędownika"1. Prymarną funkcję opiekuńczą świętego wobec kościoła, diecezji, ale też miasta, kraju, bractwa czy zawodu podkreśla łaciński źródłosłów terminu „patron” - „obrońca”, „opiekun”, funkcjonu-

Dr Renata JANicka-Szyszko - dyrektor Akademickiego Liceum Mistrzostwa Sportowego w Gorzowie Wielkopolskim, wykładowca Akademii im. Jakuba z Paradyża w Gorzowie Wielkopolskim; adres do korespondencji: ul. Teatralna 25, 66-400 Gorzów Wielkopolski; e-mail: janickaszyszko@gmail.com. ORCID 0000-0002-5396-6613.

${ }^{1}$ Religia. Encyklopedia PWN, red. nauk. T. Gadacz, B. Milerski, t. 8, Wydawnictwo Naukowe PWN, Warszawa 2003, s. 32. 
jącego w polszczyźnie od XV wieku². Wielowiekowa tradycja posiadania przez właściwie każdą grupę zawodową, ale też wiele grup środowiskowych, duchowego opiekuna, religijnego patrona funkcjonuje nieprzerwanie również w czasach współczesnych, co potwierdza m.in. zarejestrowane w Uniwersalnym stowniku języka polskiego jedno ze znaczeń wyrazu „patron”. Zostało ono opatrzone kwalifikatorem „rel.”, wskazującym nie tylko na nacechowanie stylistycznie, ale przede wszystkim na związek z religią, co poświadcza obecna $\mathrm{w}$ definicji fraza: „w chrześcijaństwie: święty, którego imię nadano komuś w czasie chrztu lub pod którego opiekę oddaje się kraje, miasta, obiekty, zawody"3.

Wyrazistą grupą społeczną, która ma swojego patrona, identyfikuje się z nim i często do niego odwołuje, tworzą myśliwi. Ich obecność na ziemiach polskich początkowo była związana ze zdobywaniem żywności, a także potrzebą zapewnienia sobie okrycia, ochrony siebie i swojego dobytku przed dzikimi zwierzętami ${ }^{4}$. Z czasem, na co wpływ miał rozwój rolnictwa, rola łowiectwa uległa zmianie - myślistwo stało się charakterystyczne dla panujących i magnaterii, gdyż na podstawie tak zwanego ius regale przyznano im prawo polowania, które stanowiło dla nich raczej przyjemność, a nie konieczność ${ }^{5}$. Jak twierdził Zygmunt Gloger, łowiectwo w Polsce „należało do kultury jego mieszkańców". W historii łowiectwa odnajdujemy kilku patronów, których polujący otaczali czcią, zwracali się z prośbami o obronę, opiekę i błogosławieństwo dla ich pasji.

Przedmiotem badań w niniejszym artykule będzie sposób ukazania postaci św. Huberta oraz próba językowej analizy - w zakresie formalnym i językowo-stylistycznym - jego kreacji w artykułach prasowych, z których został wyekscerpowany materiał językowy (przede wszystkim leksyka i frazeologia ${ }^{7}$ ), a mianowicie $\mathrm{z}$ tekstów opublikowanych w latach 2015-2019

\footnotetext{
${ }^{2}$ A Bańkowski w swoim opracowaniu wyraz patron wywodzi od łacińskiego patrōnus (od pater, patris 'ojciec'). Por. A. BAŃKOWski, Etymologiczny słownik języka polskiego, t. 2, Wydawnictwo Naukowe PWN, Warszawa 2000, s. 516.

${ }^{3}$ Uniwersalny słownik języka polskiego, red. S. Dubisz, Wydawnictwo Naukowe PWN, t. 3, Warszawa 2003, s. 75 (dalej USJP).

${ }^{4}$ Por. Ilustrowana encyklopedia Trzaski, Everta i Michalskiego, red. S. Lam, t. 3, Wydawnictwo Trzaska, Evert i Michalski, Kraków 1928, s. 246.

${ }^{5}$ Tamże.

${ }^{6}$ Z. Gloger, Encyklopedia staropolska ilustrowana, t. 3, Wydawnictwo „Wiedza Powszechna”, Warszawa 1972, s. 165.

${ }^{7}$ Według A.M. Lewickiego i R. Tokarskiego najwięcej informacji dotyczących językowego obrazu świata można zdobyć, obserwując właśnie leksykę i składnię. Por. Kreowanie świata w tekstach, red. A.M. Lewicki, R. Tokarski, Wydawnictwo Uniwersytetu Marii Curie-Skłodowskiej, Lublin 1995, s. 7.
} 
w „Łowcu Polskim”, wydawanym od 1899 r. miesięczniku o tematyce przyrodniczo-łowieckiej ${ }^{8}$. Za Elżbietą Skorupską-Raczyńską przyjmuję, że termin językowa kreacja oznacza „tworzenie w dziele literackim wizerunku kogoś i/lub czegoś przez jego autora, antropocentrycznie postrzegającego opisywaną, odtwarzaną i/lub tworzoną rzeczywistość, posiadającego właściwe mu, osobnicze zasoby słownikowe i umiejętności odpowiedniego stylistycznie ich wykorzystania"9. Mimo że analizowane teksty mają wielu autorów, uznaję za zasadne zastosowanie powyższego pojmowania językowej kreacji, gdyż piszących łączą myśliwskie pasje i zainteresowanie tematyką przyrodniczą, podobny stosunek do opisywanej rzeczywistości, zbliżone doświadczenia, porównywalny system wartości, a tym samym również postrzeganie przez nich opisywanej, odtwarzanej i/lub tworzonej rzeczywistości jest tożsame, stylistyczne zaś wykorzystanie zasobów słownikowych ma wiele cech wspólnych.

Błogosławieni czy święci będący patronami poszczególnych grup często wykonywali ten sam zawód lub w inny sposób kojarzyli się z daną profesją, niekiedy jednak trudno ustalić związek między daną grupą zawodową a osobą religijnego opiekuna ${ }^{10}$. Patroni myśliwych albo sami polowali, albo z ich osobą związane są atrybuty charakterystyczne także dla łowiectwa.

\footnotetext{
${ }^{8}$ Wszystkie analizowane terminy, które tworzą językową kreację św. Huberta, będą cytowane bez podawania tytułów i autorów poszczególnych artykułów, aby zachować konsekwencję zapisu, ponieważ wiele treści umieszczanych w miesięczniku nie jest podpisywanych. Po cytacie podany zostanie rok i numer miesięcznika „Łowiec Polski” (dalej ŁP) oraz strona, z której dany wyimek pochodzi.

${ }^{9}$ E. SKORUPSKA-RACZYŃSKA, Kreacja ojca w powieściach nadniemeńskich Elizy Orzeszkowej (studium językowo-stylistyczne), Wydawnictwo Naukowe Akademii im. Jakuba z Paradyża w Gorzowie Wielkopolskim, Gorzów Wielkopolski 2013, s. 22.

${ }^{10}$ Przykładem mogą być patroni cechów rzemieślniczych. Zob. R. JANICKA-SzYszKo, Językowa kreacja Józefa Cieśli w powieści Jana Dobraczyńskiego „Cień Ojca”, w: Język doświadczenia religijnego, t. X, red. G. Cyran, E. Skorupska-Raczyńska, Wydawnictwo Naukowe Akademii im. Jakuba z Paradyża w Gorzowie Wielkopolskim, Gorzów Wielkopolski 2017, s. 66. Podobną sytuację można zaobserwować w przypadku patronów szewców - święci Kryspin i Kryspinian, pochodzący z rzymskiej rodziny szlacheckiej, późniejsi męczennicy, głosili Ewangelię na terenie północnej Francji w drugiej połowie III wieku; aby zarobić na utrzymanie, nocami pracowali jako szewcy. Z kolei patronka fryzjerów i perukarzy, św. Maria Magdalena standardowo przedstawiana jest jako kobieta mająca piękne, długie włosy, co przywodzi na myśl Ewangelię św. Łukasza, w której opisana została jawnogrzesznica (Łk 7,36-50) włosami wycierająca namaszczone wcześniej nogi Jezusa. Rzeźnicy i wędliniarze z Gorzowa Wielkopolskiego umieścili na swojej chorągwi św. Błażeja. Biografia tego świętego nie wskazuje na związki z tymi grupami zawodowymi, a źródła suponują, że jest on patronem innych rzemiosł. Por. V. ScHAUBer, H.M. Schindler, Święci na każdy dzień. Patroni naszych imion, Wydawca Świat Książki, Warszawa 2000, s. 50, 371-373, 552-553.
} 
We wczesnej fazie łowiectwa podstawowe narzędzie polujących stanowił łuk, stąd zapewne kult ${ }^{11}$ św. Sebastiana, którego czcili ludzie wykorzystujący tę broń, a więc także i myśliwi. Żyjący w III wieku n.e. św. Sebastian, przywódca gwardii cesarza Marka Aurelego Probusa (cesarz rzymski w latach 276-282) oraz dowódca przybocznej straży Dioklecjana (cesarz rzymski w latach 284-305), za wyznawanie nauki Chrystusa poniósł męczeńską śmierć przeszyty strzałami z łuku ${ }^{12}$.

Już od czasów starożytności chrześcijańskiej duchową opieką otaczał myśliwych św. Eustachy Rzymski, który żył na przełomie I i II wieku. Początkowo jako dowódca armii cesarskiej prześladował chrześcijan, w wyniku jednak widzenia w czasie polowania, kiedy to ukazał mu się jeleń z krzyżem pośrodku poroża, przyjął chrzest i stał się gorliwym chrześcijaninem. Wierność Bogu i odmowa złożenia pogańskiej ofiary doprowadziła go do męczeńskiej śmierci - został żywcem spalony. Kult świętego, związany zapewne z myśliwską pasją Eustachego oraz jego cudowną przemianą, której doznał właśnie w czasie polowania, w zachodniej Europie trwał do ok. XII wieku, w Polsce zaś rozwijał się od początków chrześcijaństwa do XVII wieku ${ }^{13}$.

Jedną z gałęzi łowiectwa jest sokolnictwo. Sokolnicy polują przy użyciu wytresowanych uprzednio ptaków drapieżnych. Ich patronem został św. Bawo(n), przedstawiany zwykle $z$ sokołem w ręku lub na ramieniu, co ma związek z legendą utrwalającą wizerunek żyjącego w VII wieku arystokraty jako bogobojnego i uczciwego mężczyzny. Został on niesłusznie oskarżony o kradzież cennego ptaka do polowania i skazany na karę śmierci, od której uratował go biały sokół, który usiadł na ramieniu późniejszego świętego i tym samym potwierdził niewinność niesłusznie skazanego ${ }^{14}$.

\footnotetext{
${ }^{11}$ Według Religia. Encyklopedia PWN (t. 6, s. 142-143) kult to zespół wierzeń i obrzędów wyrażających religijną cześć dla określonej postaci/obiektu sacrum. Z kolei według popularnego słownika W. Kopalińskiego kult to oddawanie czci religijnej, ubóstwianie; ogół ceremonii, praktyk religijnych, wielki szacunek, cześć dla kogo albo czego, uwielbienie; gorliwe uprawianie, rozwijanie czego. Por. W. Kopaliński, Stownik wyrazów obcych i zwrotów obcojęzycznych, Wydawnictwo „Wiedza Powszechna”, Warszawa 1988, s. 286.

${ }^{12}$ Więcej o św. Sebastianie zob. W. FrątczaK, Patroni myśliwych. Św. Eustachy, św. Hubert, św. Bawon, Wydawnictwo Duszpasterstwa Rolników, Włocławek 2002, s. 13; ŁP (2017) 11, s. 25-26; W. Zaleski, Święci na każdy dzień, Wydawnictwo Salezjańskie, Warszawa 2005, s. 47-48; V. Schauber, H.M. Schindler, Święci na każdy dzień, s. 27-28.

${ }^{13}$ Więcej św. Eustachym zob. W. FrątczaK, Patroni myśliwych, s. 13, 17-22; V. Schauber, H.M. SCHINDLER, Święci na każdy dzień, s. 488-489; M. LeDwosiŃSKI, ŁP (2017) 11, s. 24-25.

${ }^{14}$ Więcej o św. Bawonie zob. W. FrątczaK, Patroni myśliwych, s. 47-52; ŁP (2017) 11, s. 2526; V. Schauber, H.M. Schindler, Święci na każdy dzień, s. 509.
} 
$\mathrm{Z}$ biegiem lat, wraz z rozwojem techniki, polowania $\mathrm{z}$ wykorzystaniem łuku oraz przy użyciu ptaków drapieżnych stawały się coraz rzadsze ${ }^{15}$, co prawdopodobnie wpłynęło na osłabienie gorliwości kultu świętych Sebastiana i Bawona wśród polujących. Z kolei św. Eustachego jako patrona myśliwych sukcesywnie zastępował św. Hubert ${ }^{16}$, który został wyniesiony na ołtarze w 743 r., już w kilkanaście lat po śmierci w 727 r. Ten pochodzący z arystokratycznej rodziny przyszły święty w młodości ożenił się, a po ślubie oddał się różnorakim rozrywkom i zabawom, chętnie polował i korzystał z rozkoszy świata doczesnego. Po śmierci żony i ojca zmienił jednak swoją postawę życiową, przyjął święcenia kapłańskie, a z czasem został biskupem. Wierni szczególnie doceniali jego zasługi w krzewieniu chrześcijaństwa i umacnianiu struktur kościelnych przede wszystkim w Ardenach i Brabancji (tereny Belgii i Holandii). Kult św. Huberta najpierw rozwijał się na terenach działalności biskupa, a szczególnie przy jego grobie - najpierw w Liège, a później w Ardenach, w miasteczku Andage (później SaintHubert), gdzie do opactwa benedyktynów przeniesiono szczątki świętego, szybko jednak rozprzestrzenił się na inne tereny, szczególnie krajów Europy Zachodniej, zwłaszcza Belgii i Francji. Początkowo z prośbą o uzdrowienie zwracali się doń chorzy na wściekliznę, z czasem prośby o opiekę i błogosławieństwo dla ich pracy zaczęli kierować przedstawiciele różnych specjalności, np. kuśnierze, tokarze, matematycy, optycy, metalowcy, odlewnicy, ludwisarze, strzelcy, rzeźnicy. W sposób szczególny cześć świętemu zaczęli oddawać polujący, co tym samym wpłynęło na osłabienie kultu, jakim otaczano św. Eustachego ${ }^{17}$. Prawdopodobnie przyczyniło się do tego pocho-

\footnotetext{
${ }^{15}$ Obecnie polowanie z łukiem, dopuszczalne w wielu krajach na świecie, w Polsce jest nielegalne. Sokolnictwo, czyli sztuka układania ptaków drapieżnych do polowań, odrodziła się w latach siedemdziesiątych XX wieku, współcześnie jednak sokolnicy zajmują się przede wszystkim ochroną biologiczną lotnisk.

${ }^{16}$ Informacje o życiu św. Huberta i legendach o nim zob. W. DynaK, O kulcie św. Huberta na ziemiach polskich, w: TENŻE, Lowiectwo $w$ kulturze polskiej. Obszary $i$ ksztatty obecności, Wydawnictwo Uniwersytetu Wrocławskiego, Wrocław 2012, s. 105-160; W. FrątczaK, Patroni myśliwych, s. 25-44; R. Gnıı, Święci i błogosławieni każdego dnia. Imiennik wedtug Kalendarza Liturgicznego Kościoła Katolickiego, Wydawnictwo Kartograficzne Mapy Ścienne Beata Piętka, Katowice 2018, s. 573-574; J. MANDZiuk, Św. Hubert. Patron myśliwych podkarpackich, „Resovia Sacra” (2007/2008) 14/15, s. 169-172; W. OJRZYŃski, Cześć oddawana świętemu biskupowi Hubertowi, w: Świętemu Hubertowi cześć, red. J. Adamczewski, Wydawnictwo: Ośrodek Kultury Leśnej, Gołuchów 2008, s. 8-12; V. Schauber, H.M. Schindere, Święci na każdy dzień, s. 564; I. WerbiŃSKI, Święty Hubert, [b.w.], Włocławek 1997; W. ZaLESKI, Święci na każdy dzień, s. 690-691.

${ }^{17}$ Kult św. Eustachego, patrona myśliwych, przetrwał wśród wiernych Kościoła prawosławnego. Por. ŁP (2017) 11, s. 26.
} 
dzenie św. Huberta z terenów zachodniej Europy - był on bliższy myśliwym niż żyjący w dawnych czasach w odległym wówczas rejonie rzymski generał. Być może istotną rolę $\mathrm{w}$ umacnianiu czci świętego odegrali również możni krewni biskupa ${ }^{18}$. Patrona polujących coraz częściej zaczęto przedstawiać nie jako biskupa, ale młodego mężczyznę w stroju myśliwskim i z łowieckimi akcesoriami, jego zaś biografię od ok. XI wieku wzbogacały obecne w tekstach hagiograficznych legendarne opowieści, w których widoczny jest wpływ opowieści o św. Eustachym, dominuje zwłaszcza historia spotkania $\mathrm{z}$ jeleniem niosącym na porożu płonący krzyż i zmiana postawy życiowej pod wpływem napomnienia udzielonego przez samego Jezusa Chrystusa.

$\mathrm{Na}$ ziemiach polskich kult św. Huberta szczególnie rozpowszechniony został w XVII i XVIII wieku, w czasach panowania Augusta II Mocnego i Augusta III Sasa, władców, którzy chętnie polowali i byli orędownikami tego patrona myśliwych. W ostatnich kilkudziesięciu latach, po okresie utrudnień w oddawaniu czci św. Hubertowi w czasach PRL-u, obserwujemy ponowne ożywienie kultu świętego. Do jego przejawów zaliczamy zarówno wyrazy i wyrażenia funkcjonujące we współczesnej polszczyźnie (np. eponimy, dla których onimem bazowym jest imię świętego: „hubertowski”, „hubertowy”, „hubertówka”, „hubertowiny” i „hubertus”, liczne frazy z komponentem „święty Hubert” („Hubertus”) czy stale zwiększająca się liczba mężczyzn noszących imię Hubert ${ }^{19}$ ), jak i różnego typu formy egzystencjalne i eschatologiczne, mające charakter świecki (np. wykorzystywanie antroponimu „Hubert” w nazwach kół łowieckich, wybór świętego na patrona szkoły, organizacja „Hubertusów” - imprez, podczas których prezentuje się kulturę łowiecką i popularyzuje idee ochrony środowiska), ale przede wszystkim religijny (np. kościoły i kaplice pod wezwaniem świętego, organizowane jesienią „Msze hubertowskie”, czyli Msze ku czci św. Huberta, modlitwy skierowane do św. Huberta czy różnego typu formy małej architektury sakralnej, nazywane tradycyjnie kapliczkami, znajdujące się często w leśnych ostępach i na polanach ${ }^{20}$ ).

\footnotetext{
${ }^{18}$ Tamże, s. 26.

${ }^{19}$ Więcej zob. R. JANICKA-SzYszKo, O świętym Hubercie, patronie nie tylko myśliwych... Przyczynek do badań nad socjolektem łowieckim, w: Język doświadczenia religijnego, t. XI, red. G. Cyran, E. Skorupska-Raczyńska, Wydawnictwo Akademii im Jakuba z Paradyża, Gorzów Wielkopolski 2018, s. 111-128.

${ }^{20}$ Przykładem kultu św. Huberta mogą być różnorodne formy duchowe i materialne obecne w regionie lubuskim. Zob. R. JANICKA-SzYSZKO, Językowo-kulturowe dziedzictwo pro-Hubertowskie w regionie lubuskim, „Карпатський край” 10-11 (2018), nr 1-2, s. 221-232.
} 
Popularność kultu św. Huberta wśród myśliwych potwierdzają także artykuły opublikowane w ostatnich pięciu latach (2015-2019) W „, Lowcu Polskim". Autorzy publikujący w najstarszym tego typu polskojęzycznym miesięczniku w swoich tekstach dotyczących, zgodnie z linią czasopisma, tematyki przyrodniczo-łowieckiej, wykorzystują postać św. Huberta, przywołując zarówno postać świętego - jego myśliwską pasję, ale także działalność misyjną - jak i stosując frazy z komponentem „Hubert” („,święty Hubert”). Zwroty językowe z komponentem „Hubert” są obecne w różnych gatunkowo tekstach: artykułach (o wybitnych myśliwych), sprawozdaniach (z Mszy hubertowskich i imprez łowieckich), życzeniach (kierowanych zarówno do odbiorców indywidualnych - myśliwych wymienionych z imienia i nazwiska, jak i odbiorców zbiorowych - np. czytelników, myśliwych i ich rodzin), notatkach o kołach łowieckich. Językowa analiza wyrażeń, w których odnajdujemy imię św. Huberta (w zakresie formalnym, semantycznym i językowo-stylistycznym), pozwoli odzwierciedlić jego językową kreację tworzoną w periodyku, a tym samym odpowiedzieć na pytanie, jaki wizerunek patrona myśliwych został wykreowany w wyekscerpowanych tekstach.

Głównym określeniem, konceptualizującym św. Huberta w analizowanych tekstach jest termin „patron”, jednoznacznie wskazujący na religijnego opiekuna myśliwych. Jednostkowo odnajdujemy wyrażenie „patron myśliwych" - autor w tekście, będącym relacją z ogólnopolskiego Hubertusa zorganizowanego w 2017 r. w Rzeszowie, stwierdził:

Patron myśliwych przypomina o odpowiedzialności za świat i naturalne środowisko, uczy szacunku dla wszystkich żywych istot, nad którymi człowiek ma $\mathrm{z}$ woli Boga władzę ${ }^{21}$.

Poprzez takie dookreślenie formy patron jednoznacznie wskazał, że w życiu polujących św. Hubert zajmuje znaczącą pozycję. Podobną funkcję identyfikacyjną można przypisać zaimkom dzierżawczym „nasz” i „swój”,22, z których pierwszy najczęściej przywoływany jest w liczbie mnogiej, podkreślającej wspólnotowość grupy. Przykładowo wyrażenie „nasz patron” zostało wykorzystane w życzeniach skierowanych do czytelników i całej społeczności polujących przez władze Polskiego Związku Łowieckiego oraz redakcję „Łowca Polskiego":

\footnotetext{
${ }^{21}$ ŁP (2017) 11, s. 9.

${ }^{22}$ Por. nasz, w: USJP, t. 2. s. 851; swój, w: USJP, t. 3, s. 1463.
} 
Z okazji święta naszego Patrona

Myśliwym i dianom, szanującym polskie tradycje i łowieckie prawa, oraz tym wszystkim, którzy rozumieją istotę aktywnej ochrony przyrody, życzenia wszelkiej pomyślności

wielu spotkań ze zwierzyną

i wspaniałych efektów pracy na rzecz zachowania bioróżnorodności składają

Naczelna Rada Łowiecka

Zarząd Główny Polskiego Związku Łowieckiego

i redakcja „Łowca Polskiego,23

Z okazji dnia św. Huberta składamy czytelnikom „Łowca Polskiego” i całej myśliwskiej społeczności serdeczne życzenia pomyślnych łowów i sukcesów w każdej dziedzinie życia. Niech nasz Patron obdarza myśliwych łowieckim szczęściem i mądrością $\mathrm{w}$ działaniu na rzecz przyrody i podtrzymywania etycznych zasad, które są podstawą naszej myśliwskiej pasji ${ }^{24}$.

W relacjach z Mszy ku czci św. Huberta autorzy także posługują się określeniem „nasz patron”:

Nabożeństwo do naszego patrona św. Huberta, podobnie jak cały jego kult, wywodzą się z Francji, chociaż miejsca działalności i spoczynku świętego znajdują się w dzisiejszej Belgii ${ }^{25}$.

Ksiądz biskup podkreślił, że głos Boga, wysłuchany przez łowcę, przemienił jego życie. Nasz patron nauczył się mądrze oceniać dobra ziemskie i nieustannie zabiegać o wieczne ${ }^{26}$.

Wyrażenia z zaimkiem „nasz” zostały wykorzystane również w tekstach przedstawiających sylwetki myśliwych:

O tym, że nasz patron wynagradza wytrwałość, przekonał się, polując na kapitalnego rogacza $[\ldots]^{27}$.

Podania milczą o poczuciu humoru św. Huberta, więc nie potrafię stwierdzić, czy również ta cecha łączy go z Leszkiem. Pewne pozostaje natomiast, że poza nim nie znam wielu myśliwych, którzy podzielaliby wszystkie pasje naszego patrona ${ }^{28}$.

\footnotetext{
${ }^{23}$ ŁP (2019) 11, s. 5.

${ }^{24}$ ŁP (2018) 11, s. 3.

${ }^{25}$ ŁP (2018) 12, s. 14

${ }^{26}$ ŁP (2016) 11, s. 9.

${ }^{27}$ ŁP (2018) 7, s. 42.

${ }^{28}$ ŁP (2017) 5, s. 34.
} 
Rzadziej funkcję dookreślającą pełni zaimek „swój”, jak np. w relacji z uroczystości ku czci św. Huberta, które były organizowane w Zamościu: „Na zamojskim Rynku Wielkim myśliwi uczcili w tym roku swego patrona" ${ }^{29}$.

Wykorzystanie w powyżej zacytowanych przykładach zaimków „nasz” i „swój” podkreśla podrzędność myśliwych wobec św. Huberta, który został wybrany z grona innych świętych i uznany za najlepszego opiekuna, do którego można zwracać się z prośbami o obronę, opiekę i błogosławieństwo.

Jednostkowo, w tekście, w którym została zaprezentowana sylwetka konno jeżdżącej i polującej kobiety, członkini Zespołu Sygnalistek Myśliwskich „Klangor”, termin „patron” został dookreślony używaną w funkcji dzierżawczej formą dopełniacza zaimka „ona”: „Święty Hubert to jej patron również z tego względu, że jeździ konno"30. Tym samym podkreślono, że św. Hubert jest nie tylko patronem myśliwych, ale również jeźdźców.

Pełnienie przez św. Huberta roli opiekuna myśliwych ilustruje również utworzony od rzeczownika „patron” czasownik odrzeczownikowy „patronować ${ }^{\prime 31}$, który został wykorzystany w tekście o trzech pokoleniach myśliwych:

Święty Hubert patronuje całej rodzinie: w ślady pana Antoniego poszedł syn Bartłomiej, a wkrótce do egzaminów dla nowo wstępujących do PZŁ przystąpi wnuk Bartosz ${ }^{32}$.

Nacechowany stylistycznie czasownik ,patronować” w słownikach współczesnej polszczyzny został opatrzony kwalifikatorem „książkowy”, wskazującym na słownictwo erudycyjne, nadające podniosłego charakteru wypowiedzi.

Myśliwi otaczają swojego patrona czcią, kultem, o czym świadczą zarówno źródła historyczne, takie jak plakat zapowiadający wieczór w oflagu, zorganizowany w 1941 r., a zaprezentowany na zorganizowanej w gmachu Sejmu wystawie ukazującej wkład środowisk łowieckich w odzyskanie przez Polskę niepodległości: „Wieczór myśliwski ku czci św. Huberta, patrona polskich myśliwych"33, jak i relacja z ogólnopolskiego Hubertusa zorganizowanego w 2017 r. w Rzeszowie:

\footnotetext{
${ }^{29}$ ŁP (2019) 11, s. 10.

${ }^{30}$ ŁP (2017) 7, s. 58.

${ }^{31}$ Por. patronować, w: USJP, t. 3, s. 75: „patronować tzn. pełnić rolę opiekuna, protektora, opiekować się, popierać".

${ }^{32}$ ŁP (2018) 7, s. 42.

${ }^{33}$ ŁP (2018) 12, s. 11.
} 
Podczas uroczystości w Ogrodach Bernardyńskich podkreślano, że kult św. Huberta niczym zwornik sklepienia gotyckiej katedry łączy różne aspekty nowoczesnego łowiectwa: dbałość o zwierzostan, opiekę nad przyrodą i przemyślaną gospodarkę łowiecką. Patron myśliwych przypomina o odpowiedzialności za świat i naturalne środowisko, uczy szacunku dla wszystkich żywych istot, nad którymi człowiek ma z woli Boga władzę ${ }^{34}$.

Konceptualizując kult św. Huberta, autor posłużył się zestawieniem z terminem budowlanym „Zwornik”35. To porównanie do konstrukcyjnego zamknięcia sklepienia charakterystycznego dla gotyckich sklepień krzyżowożebrowych ${ }^{36} \mathrm{w}$ nieco patetyczny sposób podkreśla znaczenie oddawania czci św. Hubertowi przez myśliwych. Postać patrona w symboliczny sposób spaja różnorodne działania współczesnych łowców, którzy nie tylko polują, ale dbają o zwierzęta, opiekują się przyrodą, prowadzą gospodarkę łowiecką, czują się odpowiedzialni za świat, szanują zwierzęta. Piszący podkreśla, że to właśnie kult św. Huberta scala polujących, uwrażliwia ich, wskazuje, jak etycznie i odpowiedzialnie się zachowywać.

Analizowane teksty odzwierciedlają przekonanie, że św. Hubert troszczy się o myśliwych, dba o nich, sprawuje nad nimi pieczę. Konceptualizują je m.in. wyrażenia $\mathrm{z}$ komponentem „opieka”37, obecne w życzeniach skierowanych zarówno do indywidualnego, jak i zbiorowego odbiorcy:

Koleżanki i koledzy po strzelbie ślą mu za pośrednictwem naszej redakcji życzenia nieustającej opieki świętego Huberta ${ }^{38}$;

Świąt pełnych rodzinnego ciepła, opieki i życzliwości świętego Huberta, a w nowym roku wielu niezapomnianych chwil w polu i kniei

Życzą naszym czytelnikom

Naczelna Rada Łowiecka

Zarząd Główny PZI

Redakcja „,Lowca Polskiego”39.

Wyraz „opieka” występuje także w tytule artykułu poświęconego działalności myśliwych na ziemi kujawskiej w przeszłości i współcześnie. Tytuł

\footnotetext{
${ }^{34}$ ŁP (2017) 11, s. 9.

${ }^{35}$ Zwornik po pierwsze w architekturze budowlanej oznacza konstrukcyjne zamknięcie sklepienia lub łuku, zwykle zdobione; klucz; w drugim znaczeniu chodzi o coś, co spaja jakieś elementy, organizuje je w całość. Por. zwornik, w: USJP, t. 4, s. 1100.

${ }^{36}$ W. Szolginia, Architektura, Wydawnictwo Sigma-Not, Warszawa 1992, s. 183.

${ }^{37}$ Opieka to troszczenie się, dbanie o kogoś, o coś, pilnowanie kogoś, czegoś; piecza. Por. opieka, w: USJP, t. 2, s. 1270.

${ }^{38}$ ŁP (2019) 11, s. 105.

${ }^{39}$ ŁP (2018) 12, s. 3.
} 
„Pod opieką Huberta” podkreśla wiarę autora w sprawowanie pieczy przez świętego nad polującymi.

Podobne przekonanie prezentuje bohater artykułu - myśliwy wspominający swoją łowiecką przygodę:

Fakt, że w tej sytuacji udało się oddać strzał powalający pojedynka w ogniu, łowca przypisuje wyłącznie pomocy świętego Huberta ${ }^{40}$.

Wykorzystanie leksemu „pomoc"41 w odniesieniu do św. Huberta wskazuje, że myśliwi wierzą, że ich patron czuwa nad nimi, chroni ich w niebezpieczeństwie, działa na rzecz ich dobra, pomagając również w oddaniu celnego strzału, być może ratującego człowieka.

Językowej kreacji życzliwości i opiekuńczości św. Huberta w życzeniach, które $\mathrm{z}$ okazji świąt wielkanocnych swoim czytelnikom złożyła redakcja miesięcznika, służy forma „przychylność”,

Obfitości dziczyzny na wielkanocnym stole, świątecznego odpoczynku, oraz optymizmu i przychylności św. Huberta życzy redakcja „Łowca Polskiego”,3,

dzięki której zilustrowano przekonanie myśliwych o potrzebie wsparcia ich przez patrona. Polujący wychodzą z założenia, że swoje sukcesy łowieckie zawdzięczają życzliwości patrona, co konsekwentnie zostało wykorzystane również $\mathrm{w}$ informacji o ślubie jednego $\mathrm{z}$ myśliwych, zakończonej życzeniami skierowanymi ogólnie do młodej pary i szczególnie do pana młodego: „Redakcja życzy wszelkiej pomyślności młodej parze, a Łukaszowi łask św. Huberta" ${ }^{44}$. Wykorzystana w życzeniach forma „łaska"45 potwierdza, że składający życzenia chcieliby wyprosić młodemu myśliwemu przychylność patrona. Okazywanie łaski przez św. Huberta myśliwym oddaje także przymiotnik „łaskaw”46 (stanowiący składnik orzeczenia imiennego), wyko-

\footnotetext{
${ }^{40}$ ŁP (2019) 12, s. 15.

41 „Pomoc” oznacza działanie lub działania podjęte dla dobra innej osoby w celu ulżenia jej w działaniu lub ratowania w niebezpieczeństwie; pomaganie. Por. pomoc, w: USJP, t. 3, s. 336.

${ }^{42}$ Przychylność - rzeczownik od ,,przychylny”. Przychylny to życzliwie, przyjaźnie usposobiony do kogoś. Por. przychylność, w: USJP, t. 3, s. 773.

${ }^{43}$ ŁP (2018) 3, s. 3.

${ }^{44}$ ŁP (2018) 10, s. 104

45 „Łaska” oznacza okazywanie komuś względów, czyjaś przychylność, wspaniałomyślność, wyróżnianie, faworyzowanie kogoś lub czegoś. Por. łaska, w: USJP, t. 2, s. 496.

${ }^{46}$ „Łaskaw” to okazujący łaskę, przyjaźnie, życzliwie usposobiony, wielkoduszny, wspaniałomyślny, dobry; w innym znaczeniu to będący wyrazem łaski; przyjazny, życzliwy. Por. taskaw, w: USJP, t. 2, s. 496-497.
} 
rzystany w relacji z polowania będącego częścią III Hubertusa Pułtuskiego, który w 2016 r. zorganizowany został na terenie Puszczy Białej: „Mimo kapryśnej aury na polowaniu stawiła się ponad setka myśliwych, a św. Hubert był łaskaw swoim wyznawcom" ${ }^{\text {"47 }}$.

Poprzez wykorzystanie formy „łaskaw”, która leksykograficznie została zakwalifikowana do słownictwa książkowego, autor konceptualizuje wizerunek patrona i przyjaznego myśliwym, i życzliwego wobec nich.

W kreowanym w czasopiśmie wizerunku św. Huberta często są wykorzystywane formy werbalne, nazywające czynności przypisywane patronowi myśliwych. W tytule opowieści o myśliwym, który zranił się w czasie polowania, musiał przejść trzy operacje i długotrwałą rehabilitację, został wykorzystany czasownik „czuwać”48: „Hubert czuwał jednak nad swoim sługą” (2017, 9, s. 94). Zarówno komponent „czuwać” w zwrocie „Hubert czuwał", jak i treść artykułu odzwierciedlają wiarę autora i bohatera artykułu, że powrót do pełnej sprawności i możliwość polowania myśliwy zawdzięcza wsparciu swojego patrona.

Przekonanie o mocy św. Huberta do obdarowywania polujących cennymi darami podkreśla zastosowana w cytowanych już życzeniach, skierowanych przez redakcję czasopisma $\mathrm{z}$ okazji święta patrona myśliwych, forma werbalna „obdarzać”49:

Z okazji dnia św. Huberta składamy czytelnikom „Lowca Polskiego” i całej myśliwskiej społeczności serdeczne życzenia pomyślnych łowów i sukcesów w każdej dziedzinie życia. Niech nasz Patron obdarza myśliwych łowieckim szczęściem i mądrością $\mathrm{w}$ działaniu na rzecz przyrody i podtrzymywania etycznych zasad, które są podstawą naszej myśliwskiej pasji ${ }^{50}$,

charakterystyczna dla języka pisanego (o czym świadczy jej kwalifikator książkowy), co nadało podniosłego charakteru wypowiedzi. Jej użycie przez składających życzenia kreuje obraz patrona, który obdarza myśliwych tym, co jest dla nich najcenniejsze - powodzeniem na łowach, ale i mądrością oraz etycznymi zasadami $w$ ich działaniach na rzecz przyrody. Konsekwentnie taki obraz działalności św. Huberta ilustruje w kolejnym tekście dotyczącym łowieckich przygód jednego z myśliwych werbalizm książkowy

\footnotetext{
${ }^{47}$ ŁP (2016) 11, s. 61.

${ }^{48}$ Czuwać to strzec, pilnować kogoś, czegoś. Por. czuwać, w: USJP, t. 1, s. 534.

${ }^{49}$ Obdarzać to ofiarować (ofiarowywać) komuś coś, zwykle cennego; obdarować (obdarowywać). Por. obdarzać, w: USJP, t. 2, s. 1046.

${ }^{50}$ ŁP (2018) 11, s. 3.
} 
„wynagradzać”51: „O tym, że nasz patron wynagradza wytrwałość, przekonał się polując na kapitalnego rogacza" ${ }^{\circ 2}$, konceptualizujący przeświadczenie, że za odpowiednią postawę (np. wytrwałości), myśliwy może otrzymać nagrodę od św. Huberta. W językowej kreacji wykorzystano również charakterystyczną dla sfery religijnej formę „błogosławieństwo”, którą zilustrowano stosunek św. Huberta do myśliwych ${ }^{53}$ : „Mniejszy cel trudniej trafić. Papież ma jednak specjalne błogosławieństwo świętego Huberta" ${ }^{24}$.

Wzmocnienie frazy z komponentem „błogosławieństwo” epitetem „specjalny" ${ }^{\prime 5}$ pozwoliło nie tylko ukazać przychylność św. Huberta, ale i wyjątkowość myśliwego Antoniego Papieża, który był bohaterem artykułu.

W wyekscerpowanym materiale wyraźnie dominuje obraz świętego, od którego zależy przebieg polowania, gdyż - według myśliwych - to właśnie św. Hubert je planuje. W językowej kreacji tę cechę patrona polujących oddaje przede wszystkim nacechowany specjalistycznie termin „scena-

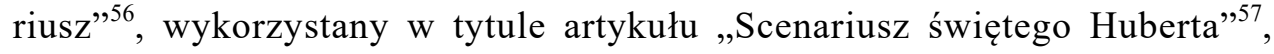
w którym opisana została historia niezwykłego polowania. Jednoznacznie wskazuje on na sprawcę polowania ustalonego przez patrona myśliwych. Podobne przekonanie prezentuje autor w artykule o niezwykłych przygodach myśliwskich: „Nie ma dwóch takich samych wypraw do lasu, a św. Hubert układa dla nas fantastyczne scenariusze" ${ }^{\text {, }}$, w którym o przemyślanym planie polowania przygotowanym przez św. Huberta świadczy forma werbalna „układać”, czyli „zaplanować (planować), zaprojektować (projektować),

${ }^{51}$ Wynagradzać to dać (dawać) nagrodę, zapłatę za coś; nagrodzić (nagradzać), zapłacić (płacić), odwdzięczyć się (odwdzięczać się). Por. wynagradzać, w: USJP, t. 4, s. 636.

${ }^{52}$ ŁP (2018) 7, s. 42.

53 „Błogosławieństwo” w religiach chrześcijańskich związane jest z obrzędem polegającym na przeżegnaniu kogoś krzyżem lub znakiem krzyża. W drugim znaczeniu dotyczy życzenia przychylności Boga, losu, wyrażone w sposób uroczysty. Może ponadto oznaczać się dobrodziejstwo, pomyślność, przychylność, szczęście. Por. błogosławieństwo, w: USJP, t. 1, s. 287.

${ }^{54}$ ŁP (2018) 7, s. 40.

${ }^{55}$ Specjalny to odnoszący się, należący do jednego wybranego przedmiotu, zagadnienia, jednej osoby, rzeczy, przeznaczony wyłącznie dla kogoś lub czegoś, do konkretnego celu. W drugim znaczeniu „specjalny” to odznaczający się czymś osobliwym; szczególny, wyjątkowy, niecodzienny. Por. specjalny, w: USJP, t. 3, s. 1315.

56 „Scenariusz” oznacza tekst stanowiący podstawę dzieła filmowego, przedstawienia teatralnego lub programu telewizyjnego, zawierający szkic fabuły utworu, ramową charakterystykę postaci i scenerię wydarzeń oraz dialogi. Ponadto „scenariusz” oznacza szczegółowo przygotowany plan, program jakiejś imprezy, jakiegoś spotkania lub też zaplanowany lub przewidywany rozwój czegoś. Por. scenariusz, w: USJP, t. 3, s. 1154.

${ }^{57}$ ŁP (2018) 7, s. 42.

${ }^{58}$ ŁP (2017) 9, s. 21. 
ustalić (ustalać), uzgodnić (uzgadniać)”,59. Określnik „fantastyczny”,60 (scenariusz), w znaczeniu typowym dla stylu potocznego, wskazuje, że przebieg takiego polowania jest niezwykły, wyjątkowy, nadzwyczajny.

Konceptualizacji wpływu św. Huberta na wynik polowania służy również tytuł artykułu sformułowany w formie równoważnika zdania „Myłkus od Huberta $^{61 "}$ (2017, 9, s. 94), w którym eliptycznie opuszczony element składniowy odbiorca tekstu może zrekonstruować, uwzględniając kontekst wypowiedzi (treść całego artykułu). Zastosowanie elipsy umożliwiło autorowi kondensację treści, z kolei czytelnik może uzupełnić tytuł artykułu opisującego historię polowania na kozła mającego zniekształcone poroże na przykłado czasowniki „otrzymać”, „uzyskać”, „odebrać”, co kreuje tym samym istotną rolę św. Huberta w ostatecznym rezultacie łowów. Podobną opinię wyraził myśliwy wspominający polowanie, które odbyło się tuż po wprowadzeniu stanu wojennego. Bohater artykułu stwierdził, że - jak uczy historia - na wypadek wojny trzeba przede wszystkim uzupełnić zapasy w spiżarniach, udany zaś rezultat polowania skomentował słowami:

Święty Hubert był najwyraźniej tego samego zdania, gdyż w pierwszym dniu stanu wojennego, polując w 14 strzelb, myśliwi z koła «Dzik» strzelili 147 zajęcy $^{62}$,

kreując w ten sposób obraz patrona jako towarzysza współczującego i rozumiejącego potrzeby swych podopiecznych.

W kreowanym w analizowanym czasopiśmie wizerunku św. Huberta podkreślana jest hierarchiczna relacja panująca między myśliwymi i ich patronem, toteż św. Hubert przedstawiany jest jako władca, rządzący, władający, zwierzchnik stojący na czele środowiska myśliwych, pan mający władzę nad myśliwymi. Językowym wyrazem takich relacji między polującymi a ich patronem są na przykład rzeczowniki „sługa” bądź „wyznawca” przypisane myśliwym: „Hubert czuwał jednak nad swoim sługą"63 i „był łaskaw swoim wyznawcom"64. Więź między św. Hubertem a środowiskiem

\footnotetext{
${ }^{59}$ Por. ułożyć - układać, w: USJP, t. 4, s. 236.

60 „Fantastyczny” oznacza nadzwyczajny, niezwykły, wyjątkowy, niepospolity, wspaniały. Por. fantastyczny, w: USJP, t. 1, s. 879-880.

${ }^{61}$ „Myłkus” oznacza samca zwierzyny płowej, zwłaszcza jelenia byka i kozła sarny, o porożu wyraźnie zniekształconym w wyniku choroby, uszkodzenia ciała (najczęściej jąder) itp. Por. S. HopPe, Stownik języka łowieckiego, Wydawnictwo PWN, Warszawa 1981, s. 140 (dalej SJŁ).

${ }^{62}$ ŁP (2018) 7, s. 41.

${ }^{63}$ ŁP (2017) 9, s. 94.

${ }^{64}$ ŁP (2016) 11, s. 61
} 
ilustruje również peryfrastyczne określenie myśliwych jako „rycerzy świętego Huberta", co odnajdujemy w rocie uroczystego przyjęcia do ich grona: „Pasuję Cię na rycerza świętego Huberta. Bądź prawym myśliwym. Darz Bór!”"65, ale także w peryfrastycznym określeniu wszystkich myśliwych, bez względu na ich łowiecki staż, co potwierdza przykład: „Jak każe tradycja, o świcie przy murach średniowiecznej twierdzy w Liwiu zebrali się na odprawie rycerze świętego Huberta" ${ }^{" 66}$.

Z kolei fraza w bezpośrednim zwrocie do myśliwych: „Szlachetni rycerze spod znaku świętego Huberta"67 została rozszerzona o wykładnik „spod znaku”, w którym komponent „znak” przywołuje termin charakterystyczny dla kultury rycerskiej: „znak herbowy”, czyli dziedziczny i potwierdzający przynależność do danego rodu ${ }^{68}$. We współczesnej polszczyźnie ingredient „znak” w bliskim znaczeniu funkcjonuje w nacechowanym książkowo frazeologizmie „ktoś, coś spod znaku czegoś, spod czyjegoś, jakiegoś znaku ktoś, coś należące do kogoś, do czegoś, ktoś będący czyimś przedstawicielem, coś mające czyjeś lub jakieś cechy charakterystyczne"69. Ten sam frazeologizm w nieco zmodyfikowanej formie odnajdujemy również $w$ tekście poświęconym polowaniom wigilijnym: „Kto bowiem w dniu tym choć chwil kilka spędzi pod znakiem świętego Huberta, ten może się spodziewać dobrego łowieckiego roku",70.

Użycie frazeologizmu „ktoś”, „coś spod znaku czegoś”, „spod czyjegoś, jakiegoś znaku" kreuje obraz św. Huberta, którego cechy charakterystyczne pragną naśladować podporządkowani mu myśliwi. Konsekwentnie potwierdzeniem tradycji pasowania adeptów łowiectwa na „rycerzy świętego Huberta” jest także tytuł artykułu „Przysięgli Hubertowi" ". Autor przedstawił w tekście relację z Mszy hubertowskiej, podczas której jedenastu młodych myśliwych złożyło przysięgę przed ołtarzem poświęconym św. Hubertowi. Zarówno nazwa „rycerze świętego Huberta”, jak i informacje o składaniu przysięgi Hubertowi wskazują, że myśliwi swoją działalnością służą swojemu patronowi, tak jak $\mathrm{w}$ średniowieczu wasal seniorowi, a tym samym

${ }^{65}$ ŁP (2017) 12, s. 19. O tradycji pasowania młodych myśliwych na rycerzy św. Huberta w regionie lubuskim zob. R. JANICKA-SzYSZKo, Językowo-kulturowe dziedzictwo, s. 226.

${ }^{66}$ ŁP (2017) 12, s. 64.

${ }^{67}$ ŁP (2017) 12, s. 15.

${ }^{68}$ Por. A. ZnAmierowski, Od znaku do herbu, w: TENŻE, Insygnia, symbole i herby polskie, Wydawnictwo Świat Książki, Warszawa 2003, s. 24-39.

${ }^{69}$ Por. znak, w: USJP, t. 4, s. 1049; zob. Słownik frazeologiczny PWN z przysłowiami, oprac. A. Kłosińska, E. Sobol, A. Stankiewicz, Wydawnictwo PWN, Warszawa 2005, s. 700 (dalej SF).

${ }^{70}$ ŁP (2019) 12, s. 73.

${ }^{71}$ ŁP (2016) 2, s. 67. 
utrwalają wizerunek św. Huberta, który jest nie tylko duchowym opiekunem myśliwych, ale i ich zwierzchnikiem.

Związek między św. Hubertem a myśliwymi został zilustrowany również w tytule artykułu o myśliwym i najbliższej mu rodzinie podzielającej jego pasje - „Klan świętego Huberta”72 - w którym komponent „klan”,73, jako wyraz charakterystyczny dla polszczyzny książkowej, konceptualizuje myśliwych jako grupę ludzi wywodzących się symbolicznie od św. Huberta.

W analizowanych tekstach został wykreowany obraz św. Huberta, który jest patronem, władcą myśliwych również po ich śmierci. Jego konceptualizacji $\mathrm{w}$ tekstach dotyczących zmarłych myśliwych służą zwroty bądź wyrażenia sytuujące św. Huberta w niebie, jak w przykładach wspomnień o wujku Benedykcie: „Niestety Benedykt szybko zasilił szeregi niebieskiej drużyny św. Huberta, w związku z czym na dłuższy czas Mateusz stracił kontakt z łowiectwem”"74; o zmarłych Dianach, czyli polujących kobietach: „Na szczególne uznanie i najwyższe noty zasługują te, które od dawna hasają po łowiskach św. Huberta" ${ }^{\text {,75 }}$ czy o zmarłym myśliwym: „,...] w połowie maja podczas polowania św. Hubert zabrał go do siebie" ${ }^{, 76}$.

Autor użytej w pierwszym cytacie metafory „zasilił szeregi niebieskiej drużyny św. Huberta” wykorzystał przekonanie o panujących pomiędzy myśliwymi i ich patronem hierarchicznych relacjach, które przypominają średniowieczne tradycje rycerskie. Tak jak w średniowieczu rycerze należeli do drużyny rycerskiej, na czele której stał wasal, tak po śmierci myśliwi stają się członkami drużyny, której przewodzi św. Hubert. W analizowanej metaforze określenie „niebieski” oprócz prymarnego określenia jednego $\mathrm{z}$ kolorów $\mathrm{z}$ kanonicznej listy barw ${ }^{77}$, zawiera nacechowane książkowo i podniośle znaczenie „dotyczący nieba jako wyobrażanego miejsca pobytu Boga, bogów, aniołów i świętych" ${ }^{, 7}$, które odnajdujemy w tekstach religijnych, co odzwierciedlają przykłady: „Królestwo Niebieskie”79, „Niebieska

\footnotetext{
${ }^{72}$ ŁP (2017) 5, s. 34.

73 „Klan” oznacza grupę ludzi wywodzących się od jednego wspólnego przodka; ród. Por. klan, w: USJP, t. 2, s. 111.

${ }^{74}$ ŁP (2018) 12, s. 34

${ }^{75}$ ŁP (2017) 5, s. 35.

${ }^{76}$ ŁP (2015) 7, s. 28.

${ }^{77}$ Kanoniczna lista barw w języku polskim zawiera następujące kolory: biały i czarny, czerwony, żółty, zielony, niebieski, brązowy, szary, fioletowy, pomarańczowy i różowy. Por. R. Tokarski, Semantyka barw we współczesnej polszczyźnie, Wydawnictwo Uniwersytetu Marii Curie-Skłodowskiej, Lublin 1995, s. 21.

${ }^{78}$ Por. USJP, t. 2, s. 898

79 „Królestwo Niebieskie” w chrześcijaństwie oznacza miejsce, gdzie przebywają Bóg, anio-
} 
Królowa”80, „niebieskie zastępy” ${ }^{\text {, }}$, „Brama niebieska”82 bądź uduchowione „przenieść się do niebieskiej chwały”, „umrzeć”83. Informacje zawarte w definicjach słownikowych określenia „niebieski” i terminu „Królestwo Niebieskie" o przebywaniu w niebie m.in. świętych pozwalają również na wskazanie nieba jako miejsca pobytu św. Huberta, który jako przebywający w niebie patron myśliwych może formować „niebieską drużynę”, składającą się z łowców, jakich - jak stwierdził autor przytoczonego powyżej kolejnego cytatu - święty „zabrał do siebie”. Wizerunek św. Huberta jako tego, który jest władcą myśliwych także po ich śmierci, zilustrowano również frazą „od dawna hasają po łowiskach świętego Huberta”, opisującą zmarłe polujące za życia kobiety. W zmetaforyzowanym wyrażeniu „łowiska świętego Huberta” autor wykorzystał typowy dla terminologii łowieckiej termin „łowisko”, którym nazywa się współcześnie w Polsce teren dzierżawiony przez prowadzące na nim gospodarkę łowiecką koło łowieckie, czyli jednostkę organizacyjną Polskiego Związku Łowieckiego. Metafora nie tylko tworzy obraz nieba jako miejsca, w którym myśliwi także po śmierci mogą polować, ale przede wszystkim kreuje obraz św. Huberta, do którego należą te tereny, który jest ich właścicielem, gospodarzem, czyli osobą najważniejszą w tym miejscu, decydującą o tym, co się w nim dzieje.

Podobnie do wyrażenia „łowiska świętego Huberta” skonstruowane są kolejne, jak np. „Miasto świętego Huberta" ${ }^{85}$ (tytuł artykułu o uroczystościach ku czci św. Huberta, które były organizowane w 2019 r. w Zamościu na Rynku Wielkim) oraz „wyższa uczelnia św. Huberta”, zastosowana w zdaniu „Oficerowie dwudziestolecia międzywojennego oprócz akademii

łowie, święci oraz dusze zbawionych. Por. królestwo niebieskie, USJP, t. 2, s. 316.

${ }^{80}$ Por. Godzinki o Niepokalanym Poczęciu Najświętszej Marii Panny, w: J. Siedlecki, Śpiewnik Kościelny, wydanie XI poprawione, Kraków 2006, s. 704-710; Hymn Godziny Czytań ze Święta Nawiedzenia Najświętszej Maryi Panny Królowo Niebieska, wesel się, w: Liturgia Godzin, t. 2: Wielki Post Okres Wielkanocny, Pallottinum, Poznań 1984, s. 1464; Królowo Niebieska, wesel się, w: http://religijne.org/galeria/Krolowo_Niebieska,_wesel_sie,_Alleluja_ 399760_1.pdf (dostęp 7.03.2020); Bądź pozdrowiona, Królowo niebieska, w: https://www.maryjni.pl/ badz-pozdrowiona-krolowo-niebieska,333 (dostęp: 7.03.2020).

${ }^{81}$ Por. Modlitwa do św. Michała Archanioła (Egzorcyzm Leona XIII), w: http://www.swmichal.pl/modlitwy-do-sw-michala-archaniola-13080 (dostęp: 7.03.2020).

${ }^{82}$ Por. Litania Loretańska do Najświętszej Maryi Panny, w: J. SiedLeCKI, Śpiewnik Kościelny, wydanie XI poprawione, Kraków 2006, s. 745-749.

${ }^{83}$ Przenieść się do niebieskiej chwaty - umrzeć. Por. SF, s. 414.

${ }^{84}$ „Łowisko” oznacza jednolite przyrodniczo gospodarstwo łowieckie, teren łowiecki, np. łowisko polne, także określona część obwodu łowieckiego, w której urządza się polowanie, albo obwód łowiecki jako jednostka gospodarcza. Por. łowisko, w: SJŁ, s. 129.

${ }^{85}$ ŁP (2019) 11, s. 10. 
wojskowych «kończyli» również wyższą uczelnię św. Huberta, która wychowała całe zastępy wytrawnych myśliwych" ${ }^{\prime 6}$. Metaforyczne konstrukcje „miasto świętego Huberta” i „wyższa uczelnia świętego Huberta” wyrażają relację posiadania przez świętego i przynależności do niego miasta czy polujących, a tym samym kreują wizerunek patrona polujących jako tego, do którego należy miasto, czy tego, kto wskazuje drogę polującym, którzy zdobywając myśliwskie szlify, „kończą” uczelnię św. Huberta.

Językowej kreacji patrona myśliwych służy także antroponim „święty Hubert” („Hubert”) wykorzystywany przez autorów analizowanych artykułów wielokrotnie w funkcji metonimicznej ${ }^{87}$. Nazwy różnego typu łowieckich imprez, takich jak np. dni hubertowskie czy wystawa łowieckiej ikonografii, zostały zastąpione $\mathrm{w}$ tytułach tekstów zamieszczonych $\mathrm{w}$, Łowcu Polskim" imieniem patrona myśliwych. Tytuł artykułu o zorganizowanej na wiślanej plaży przez Koło Łowieckie Rycerzy świętego Huberta imprezie integrującej lokalną społeczność w podwarszawskiej miejscowości Secymin brzmi „Święty Hubert nad Wisłą" ${ }^{\text {88 }}$. Z kolei relacja z otwartej w Sejmie 3 listopada 2016 r. wystawy poświęconej łowiectwu w niepodległej Polsce zatytułowana została „Hubert w sejmie” ${ }^{89}$, doniesienia zaś o obchodach dni hubertowskich w okręgu krakowskim w 2015 r. - „Hubert w Sukiennicach"90. Antroponim „święty Hubert” („Hubert”) został wykorzystany także do zastąpienia nazwy myśliwych, tym samym autorzy wykorzystali odmianę metonimii, czyli antonomazję ${ }^{91}$. Artykuł, w którym autor opisał polowanie i protesty ekologów przeciwko polującym myśliwym, został zatytułowany „Hubert kontra zieloni”, ${ }^{2}$, natomiast tekst o działalności myśliwych, którzy nie tylko polują, ale też przybliżają młodym pokoleniom problemy ochrony przyrody, na przykład organizując konkurs twórczości

${ }^{86}$ ŁP (2018) 3, s. 60. Artykuł o wpływie myśliwskich doświadczeń na postawy polskich oficerów w okresie dwudziestolecia międzywojennego.

${ }^{87}$ Metonimia to zastąpienie nazwy jakiegoś przedmiotu lub zjawiska nazwą innego, pozostającego z nim w pewnej obiektywnej zależności. Por. A. OKopień-SŁawińska, Metonimia, w: M. GŁowiński, T. Koskiewiczowa, A. OkopieŃ-SŁawińska, J. SŁawiński, Słownik terminów literackich, Zakład Narodowy im. Ossolińskich, Wrocław-Warszawa-Kraków-Gdańsk-Łódź 1988, s. 281-282 (dalej STL).

${ }^{88}$ ŁP (2018) 11, s. 78

${ }^{89}$ ŁP (2016) 12, s. 8.

${ }^{90}$ ŁP (2015) 12, s. 67.

${ }^{91}$ Antonomazja to używanie imienia własnego znanej postaci literackiej lub historycznej jako nazwy określonego typu ludzkiego. Por. A. OKOPIEŃ-SŁAWIŃSKA, Antonomazja, w: STL, s. 33.

92 ŁP (2017) 12, s. 64. 
plastycznej - „Święty Hubert ekologiem”" Z3. Zastosowanie metonimii i jej odmiany - antonomazji zakłada pozostawanie nazwy zastępującej z nazwą zastępowaną $\mathrm{w}$ jakiejś zależności. Tym samym zastąpienie przez autorów analizowanych tekstów nazw myśliwskich imprez i samych myśliwych antroponimem „święty Hubert” („Hubert”) kreuje wizerunek świętego nie tylko jako patrona myśliwych, ale także jako postaci ściśle związanej z łowiectwem, uwypuklając myśliwskie doświadczenia w jej biografii.

Reasumując, warto podkreślić, że w tekstach zamieszczonych w ostatnich pięciu latach (2015-2019) w „Łowcu Polskim” postać św. Huberta została przywołana ponad 50 razy. W wyekscerpowanym materiale odnajdujemy wykreowany przez piszących pozytywny, wręcz ciepły wizerunek otaczanego kultem patrona polujących. Jako opiekun myśliwych dba on o nich, troszczy się, wspiera ich, czuwa nad nimi, sprawuje nad nimi pieczę, ratując w niebezpieczeństwie, strzegąc od złego, wskazując im drogę postępowania. Wobec łowców jest przyjazny i życzliwy, okazuje im swą łaskę i przychylność, działa na rzecz ich dobra, na przykład pomagając w oddaniu celnego strzału. Piszący tworzą obraz św. Huberta obdarzonego mocą nagradzania i obdarowywania za właściwe zachowania polujących cennymi dla nich darami, między innymi powodzeniem na łowach, umiejętnością kierowania się etycznymi zasadami w czasie polowania czy mądrością w działaniach na rzecz przyrody. Dla myśliwych najcenniejsze są sukcesy łowieckie, stąd w językowej kreacji świętego dominuje wizerunek tego, który odgrywa decydującą rolę w czasie polowania, ponieważ to od patrona zależy przebieg łowów, gdyż to właśnie on je planuje, ustala ich porządek. W analizowanych tekstach wykreowany został obraz patrona zajmującego w życiu myśliwych znaczącą pozycję, stojącego na ich czele, będącego ich zwierzchnikiem, władcą, nie tylko za życia polujących, ale także po ich śmierci, stąd wizerunek św. Huberta, który jest dla łowców przewodnikiem w Królestwie Niebieskim. W językowej kreacji św. Huberta istotny jest również obraz myśliwych, którzy, akceptując hierarchiczność relacji między nimi a ich patronem, pragną mu wiernie i oddanie służyć swoją działalnością, naśladować jego cechy charakterystyczne, szczególnie jako postaci ściśle związanej z łowiectwem, co sygnalizuje się, przywołując myśliwskie doświadczenia w biografii świętego oraz wskazując na wywodzenie się od niego innych polujących.

\footnotetext{
${ }^{93}$ ŁP (2015) 5, s. 71.
} 
Konceptualizacji tak pozytywnego obrazu patrona myśliwych służą różne środki językowo-stylistyczne. Na przykład w językowej kreacji wykorzystany został termin patron dopełniony zarówno przez określenie „myśliwych", jak i zaimki dzierżawcze w liczbie mnogiej nasz i swój oraz używaną $\mathrm{w}$ funkcji dzierżawczej formą dopełniacza zaimka ona (jej patron). Szczególny obraz św. Huberta kreują różnorodne formy nominalne, jak na przykład „opieka”, „pomoc”, „przychylność”, „życzliwość”; formy werbalne: „czuwać”, „patronować”, „obdarzać”, „wynagradzać”; charakterystyczne dla sfery religijnej terminy, na przykład „błogosławieństwo”, „kult”, „łaska”, „wyznawca”; typowe dla hierarchicznej relacji i kultury rycerskiej, jak m.in. „klan”, „przysięgać”, „,ługa”, „drużyna świętego Huberta”, „,rycerze (spod znaku) świętego Huberta"; terminologia łowiecka, by przywołać dla przykładu: „myłkus” i „łowisko” („łowisko świętego Huberta”); zmetaforyzowane wyrażenia, wskazujące, że coś znajduje się pod panowaniem św. Huberta: „miasto świętego Huberta”, „wyższa uczelnia św. Huberta”; lub jest od niego zależne: „święty Hubert układa dla nas fantastyczne scenariusze".

Językowej kreacji patrona myśliwych służą frazeologizmy w ich formie podstawowej, na przykład „ktoś, coś spod znaku czegoś”, „spod czyjegoś, jakiegoś znaku” „ktoś, coś należące do kogoś, do czegoś, ktoś będący czyimś przedstawicielem, coś mające czyjeś lub jakieś cechy charakterystyczne”, jak w wyrażeniu „rycerze spod znaku świętego Huberta” oraz zwrotach „wojna”, „choroba”, „śmierć” itp. „kogoś zabrała”, jak we frazie „święty Hubert zabrał go do siebie”. Sporadycznie w analizowanych tekstach kreujących wizerunek św. Huberta odnajdujemy porównania, na przykład „kult świętego Huberta niczym zwornik sklepienia gotyckiej katedry łączy różne aspekty nowoczesnego łowiectwa", podkreślające funkcję kultu św. Huberta spajającą środowisko myśliwych, oraz metafory, na przykład „zasilił szeregi niebieskiej drużyny świętego Huberta”, „łowiska świętego Huberta", plastycznie obrazujące śmierć i zaświaty. Językowy obraz św. Huberta kreuje także wykorzystanie antroponimu „święty Hubert” („Hubert”) w funkcji metonimicznej i jej odmianie - antonomazji. Hasła „Hubert w sejmie”, „Hubert w Sukiennicach”, „Hubert kontra zieloni”, „święty Hubert ekologiem”, „święty Hubert nad Wisłą”, podkreślają zależność między myśliwymi i myśliwskimi imprezami oraz św. Hubertem, a jednocześnie kreują wizerunek świętego jako postaci współcześnie ściśle związanej z łowiectwem. 
Językową kreację patrona myśliwych uzupełnia nacechowanie stylistyczne analizowanych wyrazów i frazeologizmów. Wizerunek szlachetnego świętego tworzy dominujące słownictwo nacechowane oficjalnością, opatrzone w wykorzystanych słownikach kwalifikatorami książkowy („łaskaw”, „klan”, „obdarzony”, „scenariusz”, „wynagradzać”, „zwornik”, „ktoś, coś spod znaku czegoś”, „spod czyjegoś, jakiegoś znaku”) i podniosły („,błogosławieństwo"), które wskazują na przynależność w najnowszej polszczyźnie do słownictwa starannego. Jednostkowo natomiast wykorzystano określenie „fantastyczny”, zaliczane do słownictwa codziennego, typowego dla kontaktów nieoficjalnych.

Językowa analiza zgromadzonego materiału potwierdza, że w wyekscerpowanych tekstach funkcjonuje pozytywny wizerunek św. Huberta, a jednocześnie wskazuje, jak ważny jest on dla myśliwych połączonych wspólną pasją, a także stanowi potwierdzenie, jak znaczącą rolę w życiu człowieka odgrywa patron.

O tym, jak istotna jest potrzeba posiadania patrona, otaczania go czcią i upamiętniania go, może świadczyć także inicjatywa, która pojawiła się w ostatnich kilku latach wśród myśliwych związanych z lasami spalskimi. W Nadleśnictwie Smardzewice, na granicy powiatów tomaszowskiego i opoczyńskiego, powstał Panteon Opiekunów Łowiectwa. Według wiedzy jego inicjatorów - jedyny w Polsce i prawdopodobnie także na świecie. Impulsem do jego stworzenia stała się wybudowana w 2012 r. kapliczka św. Huberta. Inicjator Panteonu, Bogusław Moraczewski, tak wyjaśnia cel stworzenia takiego miejsca: „Zależało mi, aby w ten sposób podkreślić więź łączącą współczesnych myśliwych z naszymi tradycjami i ojczystą przyrodą" ${ }^{4}$. W galerii, oprócz kapliczki poświęconej św. Hubertowi, znalazły się drewniane rzeźby antycznych opiekunek lasów i zwierząt, bogini łowów (Artemidy i Diany), słowiańskiej opiekunki przyrody, władczyni lasów i gajów (Dziewanny), św. Bawona, św. Eustachego, św. Idziego, patrona myśliwych i łuczników ${ }^{95}$, św. Franciszka z Asyżu ${ }^{96}$, a także św. Krzysztofa, patrona wędrowców, który według autora artykułu „zaprasza przejeżdżających przez spalskie lasy do zatrzymania się i odbycia duchowej

\footnotetext{
${ }^{94}$ Por. ŁP (2019) 11, s. 82.

${ }^{95}$ Św. Idzi uważany jest za patrona myśliwych i łuczników, do czego przyczyniła się legenda o uratowaniu łani przez świętego, który swoim ciałem ochronił zwierzę przed zranieniem strzałą wypuszczona przez króla. Św. Idzi jest czczony m.in. przez myśliwych bawarskich. Por. V. Schauber, H. M. Schindler, op. cit., s. 453-454.

${ }^{96}$ Por. tamże, s. 513-516.
} 
podróży"97. W planach jest jeszcze uzupełnienie panteonu o rzeźby świętych: Jana Gwalberta, patrona leśników i pracowników leśnych ${ }^{98}$, Sebastiana, Wincentego, patrona drwali ${ }^{99}$, Rocha, opiekuna rolników i ogrodników ${ }^{100}$ oraz Emeryka ${ }^{101}$.

\section{BIBLIOGRAFIA}

BAŃKOwSKI A., Etymologiczny słownik języka polskiego, t. 2, Wydawnictwo Naukowe PWN, Warszawa 2000.

Bądź pozdrowiona, Królowo niebieska, w: https://www.maryjni.pl/badz-pozdrowiona-krolowoniebieska,333 (dostęp 7.03.2020).

DynaK W., O kulcie św. Huberta na ziemiach polskich, w: Tenże, Łowiectwo w kulturze polskiej. Obszary i kształty obecności, Wydawnictwo Uniwersytetu Wrocławskiego, Wrocław 2012.

Encyklopedia PWN, red. nauk. T. Gadacz, B. Milerski, t. 6, Wydawnictwo Naukowe PWN, Warszawa 2002

Encyklopedia PWN, red. nauk. T. Gadacz, B. Milerski, t. 8, Wydawnictwo Naukowe PWN, Warszawa 2003.

Frątczak W., Patroni myśliwych, Wydawnictwo Duszpasterstwa Rolników, Włocławek 2002.

Gloger Z., Encyklopedia staropolska ilustrowana, Wydawnictwo „Wiedza Powszechna”, t. 3, Warszawa 1972.

GNıŁA R., Święci i błogosławieni każdego dnia. Imiennik według Kalendarza Liturgicznego Kościoła Katolickiego, Wydawnictwo Kartograficzne Mapy Ścienne Beata Piętka, Katowice 2018.

GŁowiński M., Koskiewiczowa T., Okopień-SŁawińsKa A., SŁawiŃski J., Słownik terminów literackich, Zakład Narodowy im. Ossolińskich, Wrocław-Warszawa-Kraków-GdańskŁódź 1988.

Hoppe S., Słownik języka łowieckiego, Wydawnictwo PWN, Warszawa 1981.

Ilustrowana encyklopedia Trzaski, Everta i Michalskiego, red. S. Lam, t. 3, Wydawnictwo Trzaska, Evert i Michalski, Kraków 1928.

JANICKA-SzYszko R., Językowa kreacja Józefa Cieśli w powieści Jana Dobraczyńskiego „Cień Ojca”, w: Język doświadczenia religijnego, t. X, red. G. Cyran, E. Skorupska-Raczyńska,

${ }^{97}$ Por. ŁP (2019) 11, s. 83.

${ }^{98}$ Święty Jan Gwalbert jest patronem leśników i pracowników leśnych. Por. V. Schauber, H.M. SCHINDLER, Święci na każdy dzień, s. 351.

${ }^{99}$ Wincenty Ferreriusz, żyjący w XIV/XV w. zakonnik, kaznodzieja, uważany jest za patrona m. in. drwali. Por. V. Schauber, H.M. Schinder, Święci na każdy dzień, s. 142.

${ }^{100}$ Święty Roch z Montpellier uważany jest za patrona m. in. rolników i ogrodników. Por. V. Schauber, H.M. SchindLer, Święci na każdy dzień, s. 426.

${ }^{101} \mathrm{Na}$ kilka dni przed koronacją Emeryk, syn króla węgierskiego, uległ w czasie polowania wypadkowi, w wyniku którego zmarł. Por. V. SCHAuber, H.M. SCHINDLER, Święci na każdy dzień, s. 570. 
Wydawnictwo Naukowe Akademii im. Jakuba z Paradyża w Gorzowie Wielkopolskim, Gorzów Wielkopolski 2017.

JANICKA-SzYszko R., Językowo-kulturowe dziedzictwo pro-Hubertowskie w regionie lubuskim w: „Карпатський край” 10-11 (2018) nr 1-2, s. 221-232.

JANICKA-SzYszko R., O świętym Hubercie, patronie nie tylko myśliwych... Przyczynek do badań nad socjolektem łowieckim, w: Język doświadczenia religijnego, t. XI, red. G. Cyran, E. Skorupska-Raczyńska, Wydawnictwo Naukowe Akademii im. Jakuba z Paradyża w Gorzowie Wielkopolskim, Gorzów Wielkopolski 2018.

Kopaliński W., Słownik wyrazów obcych i zwrotów obcojęzycznych, Wydawnictwo „Wiedza Powszechna", Warszawa 1988.

Kreowanie świata w tekstach, red. A.M. Lewicki, R. Tokarski, Wydawnictwo Uniwersytetu Marii Curie-Skłodowskiej, Lublin 1995.

Królowo Niebieska, wesel się, w: http://religijne.org/galeria/Krolowo_ Niebieska,_wesel_ sie,_Alleluja_399760_1.pdf(dostęp: 7.03.2020).

Liturgia Godzin, t. 2, Wielki Post, Okres Wielkanocny, Pallottinum, Poznań 1984.

Łowiec Polski, numery wykorzystanych tekstów 5 (2015), 7 (2015), 12 (2015), 11 (2016), 12 (2016), 5 (2017), 7 (2017), 9 (2017), 11 (2017), 12 (2017), 3 (2018), 7 (2018), 10 (2018), 11 (2018), 12 (2018), 8 (2019), 11 (2019), 12 (2019).

MandziuK J., Św. Hubert. Patron myśliwych podkarpackich, „Resovia Sacra” 14/15 (2007/2008).

Modlitwa do św. Michała Archanioła (Egzorcyzm Leona XIII), w: http://www.swmichal.pl/modlitwy-do-sw-michala-archaniola-13080 (dostęp: 7.03.2020).

OJRZYŃSKI W., Cześć oddawana świętemu biskupowi Hubertowi, w: Świętemu Hubertowi cześć, red. J. Adamczewski, Wydawnictwo: Ośrodek Kultury Leśnej, Gołuchów 2008.

Schauber V., Schindler H.M., Święci na każdy dzień. Patroni naszych imion, Wydawca Świat Książki, Warszawa 2000.

SiedleCKI J., Śpiewnik Kościelny, wydanie XI poprawione, Kraków 2006.

SKORUPSKA-RACZYŃSKa E., Kreacja ojca w powieściach nadniemeńskich Elizy Orzeszkowej (studium językowo-stylistyczne), Gorzów Wielkopolski 2013.

Słownik frazeologiczny PWN z przysłowiami, oprac. A. Kłosińska, E. Sobol, A. Stankiewicz, Wydawnictwo Naukowe PWN, Warszawa 2005.

SoJKa H., Opiekunowie myśliwych, „Łowiec Polski” (2019), nr 11.

Szolginia W., Architektura, Wydawnictwo Sigma-Not, Warszawa 1992.

TOKARSKi R., Semantyka barw we współczesnej polszczyźnie, Wydawnictwo Uniwersytetu Marii Curie-Skłodowskiej, Lublin 1995.

Uniwersalny słownik języka polskiego, red. S. Dubisz, Wydawnictwo Naukowe PWN, Warszawa 2003, t. 1-4.

WerbiŃSKi I., Święty Hubert, [b.w.], Włocławek 1997.

ZALESKi W., Święci na każdy dzień, Wydawnictwo Salezjańskie, Warszawa 2005.

Znamierowski A., Od znaku do herbu, w: Tenże, Insygnia, symbole i herby polskie, Wydawnictwo Świat Książki, Warszawa 2003. 


\section{JĘZYKOWA KREACJA ŚWIĘTEGO HUBERTA NA PRZYKŁADZIE MIESIĘCZNIKA „LOWIEC POLSKI”}

\section{Streszczenie}

Celem artykułu jest próba językowej analizy kreacji św. Huberta w artykułach opublikowanych w latach 2015-2019 w „Łowcu Polskim”. W różnych gatunkowo tekstach: artykułach, sprawozdaniach, życzeniach, notatkach patron myśliwych został przywołany ponad 50 razy. Językowy obraz świętego Huberta kreują różne środki językowo-stylistyczne. Oprócz form nominalnych i werbalnych odnajdujemy frazeologizmy, porównania, zmetaforyzowane wyrażenia, wyrazy i zwroty typowe dla hierarchicznej relacji i kultury rycerskiej, terminologię zarówno religijną, jak i łowiecką. Analiza wskazuje, iż w wyekscerpowanych tekstach funkcjonuje pozytywny wizerunek opiekuna myśliwych. Święty Hubert troszczy się o nich, okazuje im swą łaskę, odgrywa decydującą rolę w czasie polowania, nagradza polujących powodzeniem w czasie łowów. W życiu myśliwych patron odgrywa znaczącą rolę, jest władcą nie tylko za życia polujących, ale i po ich śmierci, zaś oni służą mu wiernie.

Słowa kluczowe: lingwistyka; leksyka; semantyka; św. Hubert; patron. 